\title{
Anti-inflammatory new coumarin from the Ammi majus $L$
}

Yasser Abdelaal Selim ${ }^{1 *}$ and Nabil Hassan Ouf ${ }^{2}$

\begin{abstract}
Investigation of the aerial parts of the Egyptian medicinal plant Ammi majus L. led to isolation of new coumarin, 6hydroxy-7-methoxy-4 methyl coumarin (2) and 6-hydroxy-7-methoxy coumarin (3); this is the first time they have been isolated from this plant. The structures of the compounds $(\mathbf{2} \& \mathbf{3})$ were elucidated by spectroscopic data interpretation and showed anti-inflammatory and anti-viral activity.
\end{abstract}

Graphical abstract: An efficient, one-new coumarin (2) was isolated from the aerial parts of the A. Majus L. was evaluated for their anti-viral and anti-inflammatory activities.

Keywords: phytochemistry, Ammi majus L., anti-viral activity, natural products, anti-inflammatory activity, steroids

\section{Introduction}

Fructus Ammi Majoris consists of the dried ripe fruits of Ammi majus L. (Apiaceae) [1,2]; originating Egypt, and widely distributed in Europe, the Mediterranean region, and western Asia, now cultivated in India [2]. This is widely used for the treatment of skin disorders such as psoriasis and vitiligo (acquired leukoderma) [1,3-6], and of vitiligo [1]. It is used as an emmenagogue to regulate menstruation, as a diuretic, and for treatment of leprosy, kidney stones, and urinary tract infections [7]. Numerous clinical trials have assessed the efficacy of Fructus Ammi Majoris andxanthotoxin for the treatment of vitiligo, psoriasis, and hypopigmentation tinea versicolor [4-6,8-11].

\section{Results and discussion}

\subsection{Chemistry}

The use of natural products in drug manufacturing is an ancient and well-established practice [12]. Egyptian medicinal plants are well known by their diverse uses in traditional folk medicine to cure various ailments including infectious diseases and known producers of pharmacological and anti-viral agents [13]A. majus $L$. is contraindicated in diseases associated with photosensitivity, cataract, invasive squamous-cell cancer, known sensitivity to xanthotoxin (psoralens), and in children

\footnotetext{
* Correspondence: y2selem@yahoo.com

${ }^{1}$ Faculty of Specific Education, Zagazig University, Zagazig, Egypt

Full list of author information is available at the end of the article
}

under the age of 12 years [14]. The fruits are also contraindicated in pregnancy, nursing, tuberculosis, liver and kidney diseases, human immunodeficiency virus (HIV) infections and other autoimmune diseases [15]. In this study, the isolated compounds (2-4) from A. majus $L$. were evaluated for their anti-viral activity (Figure 1 ). The major constituents are furanocoumarins, the principal compound beingxanthotoxin (methoxsalen, 8-methoxypsorale [8-MOP]) ammoidin; up to, imperatorin (ammid-in) and bergapten (heraclin, majudin, and 5methoxy Psoralen [5-MOP]) and other coumarins of significance are marmesin (the structure of isolated compounds) isoimperatorin, heraclenin, and isopimpinellin constituents of interest are acetylated flavonoids [16-20]. The dried plant (500 g) of A. majus L. was sequentially extracted with hexane and methanol. In our initial biological study as shown in Table 1 the compounds 2,3 showed high anti-inflammatory activity while the compound 4 showed moderate activity. This effect could explain the medical use of $A$. majus in traditional medicine. The hexane extract was chromatographed to give $\beta$-sitosterol 1 [21]. The methanol fraction was chromatographed on silica gel to give new coumarin 2 and two coumarins 3, 4. Compound 2 showed fluorescence under UV indicating it to be coumarin. The IR spectrum of the compound exhibited the presence of a carbonyl group at $1710 \mathrm{~cm}^{-1}$ which was a further support toward the coumarin nucleus. MS suggested its molecular mass to be 206 in agreement with the formula 

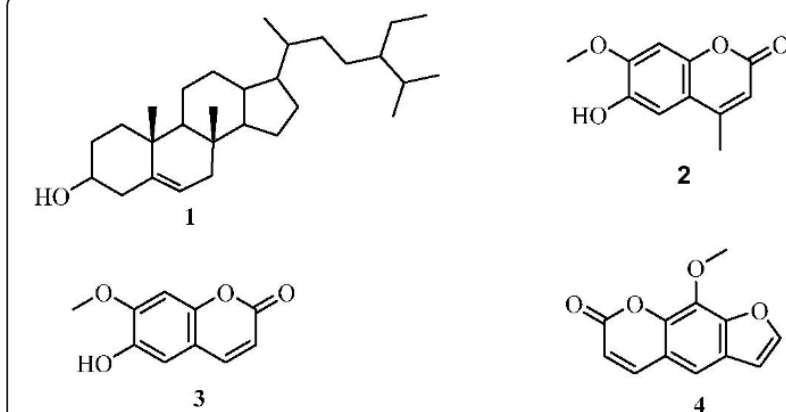

Figure 1 The structure of isolated compounds.

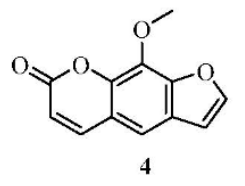

$\mathrm{C}_{11} \mathrm{H}_{10} \mathrm{O}_{4}$, which shows fragments at $m / z 193$ and 162, suggesting that fragmentation is occurring in the manner associated with coumarin nucleus. ${ }^{1} \mathrm{H}$ NMR of the compound in $\mathrm{CDCl}_{3}$ showed that no band was typical of $\mathrm{H}-4$ of a coumarin and singlet at $\delta 6.25$ was assignable to $\mathrm{H}-3$, indicating that methyl group was attached at position 4. Another doublet was observed at $\delta 6.62$, which could be $\mathrm{H}-5$ of a coumarin. There was a singlet at $\delta 6.43$ and 6.82 for two protons which represented $\mathrm{H}-6$ and $\mathrm{H}-8$ of the nucleus. The ${ }^{13} \mathrm{C}$ NMR spectrum showed resonance for all 11 carbon atoms in the molecule. The spectra revealed the presence of two methyl, three methane and six quaternary carbon atoms. The two downfield quaternary carbon signals at $\delta, 162.5$ (C3) and 143.7 (C-6) showed the presence of ketonic and one hydroxyl functionality in the molecule. The analytical results obtained from ${ }^{13} \mathrm{C}$ NMR spectrum for this compound was tabulated in Table 2. Compound 3 showed fluorescence under UV indicating it to be a coumarin. The IR spectrum of the compound exhibited the presence of a carbonyl group at $1700 \mathrm{~cm}^{-1}$ which was a further support towards the coumarin nucleus. MS suggested its molecular mass to be 192 which agreement with formula $\mathrm{C}_{10} \mathrm{H}_{8} \mathrm{O}_{4} \cdot{ }^{1} \mathrm{H}$ NMR of the compound in $\mathrm{CDCl}_{3}$ showed a doublet at $\delta 6.72$ which was typical of

Table 1 Anti-inflammatory data of the titled coumarin's compounds

\begin{tabular}{ccc}
\hline Compounds & \multicolumn{2}{c}{ Thickness of rat paw $(\mathbf{m m})$ after } \\
\cline { 2 - 3 } & $\mathbf{3} \mathbf{h}$ & \% Inhibition after $\mathbf{3 ~ h}$ \\
\hline $\mathbf{2}$ & $0.43 \pm 0.008^{\mathrm{b}}$ & 37.81 \\
$\mathbf{3}$ & $0.41 \pm 0.008^{\mathrm{b}}$ & 36.80 \\
$\mathbf{4}$ & $0.53 \pm 0.009^{\mathrm{b}}$ & 28.17 \\
Indomethacin & $0.25 \pm 0.1^{\mathrm{b}}$ & 60.50 \\
Control & $0.72 \pm 0.015$ & - \\
\hline
\end{tabular}

The results were significant.

Compared with control (carrogeenin only), ${ }^{a} p<0.05$

Compared with Indomethacin, ${ }^{\mathrm{b}} p<0.01$

H-4 of a coumarin. Another doublet was observed at $\delta$
Table $2{ }^{1} \mathrm{H}$ NMR and ${ }^{13} \mathrm{C}$ NMR chemical shifts $(\delta / \mathrm{ppm})$ of (2) and (3) DMSO- $d_{6}$ as the solvents $\left(25^{\circ} \mathrm{C}\right)$

\begin{tabular}{|c|c|c|c|c|}
\hline \multirow[t]{3}{*}{ Position } & \multicolumn{4}{|c|}{ DMSO- $d_{6}$} \\
\hline & \multicolumn{2}{|c|}{2} & \multicolumn{2}{|r|}{3} \\
\hline & ${ }^{1} \mathrm{H}$ & ${ }^{13} \mathrm{C}$ & ${ }^{1} \mathrm{H}$ & ${ }^{13} \mathrm{C}$ \\
\hline 1 & - & - & - & - \\
\hline $\mathrm{C} 2(\mathrm{C}=\mathrm{O})$ & - & 162.5 & - & 161.8 \\
\hline $\mathrm{C} 3$ & $6.29 \mathrm{~s}$ & 113.2 & $7.95 d$ & 117.05 \\
\hline $\mathrm{C} 4$ & - & 152.6 & $6.72 d$ & 147.3 \\
\hline C5 & $6.62 d$ & 109.3 & $5.35 d$ & 113.4 \\
\hline $\mathrm{C} 6(\mathrm{OH})$ & $6.43 d$ & 143.7 & $6.25 d$ & 143.6 \\
\hline$C 7$ & - & 146.8 & - & 146.2 \\
\hline $\mathrm{C} 8$ & $6.82 d$ & 104.9 & $6.80 d$ & 104.2 \\
\hline C9 & - & 147.5 & - & 149.7 \\
\hline $\mathrm{C} 10$ & - & 112.5 & - & 111.3 \\
\hline $\mathrm{C} 11\left(\mathrm{CH}_{3}\right)$ & $2.45 \mathrm{~s}$ & 19.8 & - & - \\
\hline $\mathrm{C} 12\left(\mathrm{OCH}_{3}\right)$ & $3.84 \mathrm{~s}$ & 56.3 & $3.79 \mathrm{~s}$ & 56.1 \\
\hline
\end{tabular}

5.35 which could be $\mathrm{H}-5$ of a coumarin. There was a singlet at $\delta 6.25$ and 6.80 for two protons which represented $\mathrm{H}-6$ and $\mathrm{H}-8$ of the nucleus. The analytical results obtained from ${ }^{13} \mathrm{C}$ NMR spectrum for this compound were tabulated in Table 2. To the best of the authors' knowledge, the coumarin compound 3 has not previously been isolated from this family. The ${ }^{1} \mathrm{H}$ NMR data of furancoumarin system were closely similar to compound 4, which included two doublets at $\delta 6.30$ and 8.27 attributed to the pyran ring protons $\mathrm{H}-3$ and $\mathrm{H}-4$, two other doublets at $\delta 7.19$ and 7.80 corresponding to the furan ring protons $\mathrm{H}-10$ and $\mathrm{H}-9$, and one olefinic proton at $\delta 7.20(\mathrm{~s})$ for $\mathrm{H}-8$. The data proposed compound 4 to be xanthotoxin [16-20].

\subsection{Biological studies}

\subsubsection{Anti-inflammatory activity}

The pharmacological evaluation of the tested compounds (2-4) was carried out as per the protocol specified. The anti-inflammatory activity of the synthesized compounds was carried out using the carrageenaninduced rat paw edema method. The anti-inflammatory activity data for the compounds are given in Table 1 . At the dose level of $0.01 \mathrm{mg} / 100 \mathrm{~g},(2,3)$ exhibited appreciable inhibition of edema, especially 2 , which exhibited a $87 \%$ of edema inhibition of $37.81 \%$, which was comparable to that of the standard drug indomethacin $(60.50 \%$ at $0.01 \mathrm{mg} / 100 \mathrm{~g}$ dose) where the compound 4 exhibited mild anti-inflammatory activity.

\subsubsection{Anti-viral activity}

The compounds (2-4) found to have antiviral activity, [13] against vesicular stomatitis virus (VSV) in a concentration-dependent manner at complete non-toxic concentration range 10-100 $\mu \mathrm{g} / \mathrm{ml}(\operatorname{Rf} 10(5)), 10-100 \mu \mathrm{g} /$ $\mathrm{ml}(\operatorname{Rf} 10(4))$, and 50-100 $\mu \mathrm{g} / \mathrm{ml}(\operatorname{Rf} 10(3))$, respectively. 
All these compounds are found to have no reliable antiviral activity against herpes simplex virus (HSV).

\section{Materials and methods}

\subsection{General}

The ${ }^{1} \mathrm{H}$ NMR and ${ }^{13} \mathrm{C}$ NMR spectra were recorded at 270 and $68.5 \mathrm{MHz}$, respectively, with TMS as an internal standard using a 270-MHz JEOLJNM Ex-270/4000 NMR instrument. Optical rotations were determined on a JASCO P-1020 polarimeter using a 100-mm glass microcell. IR spectra (KBr) were recorded on a PerkinElmer 1650 FT-IR spectrometer. The UV spectra were recorded with a Perkin-Elmer Lambda 2UV/VIS spectrophotometer. The melting points were determined using a Digital Melting Point Apparatus (model IA 8103, Electro thermal Engineering Ltd, Soutthend-onSea, Essex, UK). MS were measured on a GSMS-QP1000EX gas chromatograph-mass spectrometer SHIMADZU-Japan. For column chromatography, silica gel (Merk. 63-200 $\mu \mathrm{m}$ particle size) was used. TLC was carried out with Merk silica gel ${ }^{60} \mathrm{~F}_{254}$ Plates. UV light (245 and $366 \mathrm{~mm}$ ) and spraying with vanillin-sulfuric acid reagent followed by heating $(120 \mathrm{C})$ were used for detection.

\subsection{Plant material}

The aerial parts of the A. Majus $L$. were obtained from local market, Egypt, in March 2010. The plant material has been deposited at the Laboratory of Botany, Faculty of Science, and Zagazig University, Egypt.

\subsection{Extraction and isolation}

The air-dried plant $(500 \mathrm{~g})$ was powdered and extracted with hexane $(1.6 \mathrm{l})$ at room temperature $\left(25^{\circ}\right.$ C) for $30 \mathrm{~min}$, and the hexane solution was evaporated in vacuo to give a residue $(21 \mathrm{~g})$. The methanol extract $(32 \mathrm{~g})$ was obtained by the same procedure. The hexane $(20 \mathrm{~g})$ was chromatographed over silica gel (200 g) using hexane with increasing amounts of ethyl acetate (5:1) to $\beta$-sitosterol $\left(1 \mathrm{C}_{29} \mathrm{H}_{50} \mathrm{O}\right)$. It is crystallized from methanol (20 mg; from Hexane-EtOAc 9:1, $R_{\mathrm{f}}=0.22$ Light petroleum: EtOAc 2:1); mp $136^{\circ} \mathrm{C}$ (literature mp $\left.136-137^{\circ} \mathrm{C}\right)$ [22]. It responded to Liebermann-Burchard Reaction. IR $v_{\max }\left(\mathrm{KBr}, \mathrm{cm}^{-1}\right) 3427 ;{ }^{1} \mathrm{H}$ NMR $(\delta$, DMSO), $5.34(1 \mathrm{H}, \mathrm{br}, \mathrm{H}-6), 3.51(1 \mathrm{H}, \mathrm{m}, \mathrm{H}-3), 2.28-$ $1.13\left(29 \mathrm{H}, \mathrm{m}, 11 * \mathrm{CH}_{2}, 7 * \mathrm{CH}\right), 0.92\left(6 \mathrm{H}, \mathrm{s}, 2 * \mathrm{CH}_{3}\right)$, $0.83\left(3 \mathrm{H}, \mathrm{s}, \mathrm{CH}_{3}\right), 0.80\left(3 \mathrm{H}, \mathrm{s}, \mathrm{CH}_{3}\right), 0.78\left(3 \mathrm{H}, \mathrm{s}, \mathrm{CH}_{3}\right)$, $0.68\left(3 \mathrm{H}, \mathrm{s}, \mathrm{CH}_{3}\right)$; GCMS: $414(\mathrm{M}+)$. This data confirmed compound 1 to be $\beta$-sitosterol 1 [21] using a direct comparison. The methanol extract (30 g) was chromatographed on a silica gel column using successively hexane-ethyl acetates eluent to give three coumarin compounds (2-4).

\subsection{6-Hydroxy-7-methoxy-4 methyl coumarin (2}

\section{$\left.\mathrm{C}_{11} \mathrm{H}_{10} \mathrm{O}_{4}\right)$}

White, amorphous solid (53 mg; from $\mathrm{CH}_{2} \mathrm{Cl}_{2}$-EtOAc 8:2, $R_{\mathrm{f}}=0.19$ Light petroleum: EtOAc 2:1); mp 204-206 ${ }^{\circ}$ $\mathrm{C} ;[\alpha]_{\mathrm{D}}+41.4\left(\mathrm{CHCl}_{3}\right)$; UV 218; IR (KBr) $\gamma_{\max } 3620$ $(\mathrm{OH}), 1710(\mathrm{C}=\mathrm{O}) \mathrm{cm}^{-1} ;{ }^{1} \mathrm{H} \mathrm{NMR}$ and ${ }^{13} \mathrm{C}$ NMR, see Table 2; $m / z 206$ 191(100), 160(17), 143(24); anal. calcd for $\mathrm{C}_{11} \mathrm{H}_{10} \mathrm{O}_{4} \% \mathrm{C}$ 64.06, \% $\mathrm{H}$ 4.9, \% O 31.3; found \% C 64.03, \% H 4.21, \% O 31.1.

\subsection{6-Hydroxy-7-methoxy-coumarin $\left(3 \mathrm{C}_{10} \mathrm{H}_{8} \mathrm{O}_{4}\right)$}

White, amorphous powder $\left(61 \mathrm{mg}\right.$; from $\mathrm{CH}_{2} \mathrm{Cl}_{2}$-EtOAc 3:1, $R_{\mathrm{f}}=0.16$ Light petroleum: EtOAc 2:1); $\mathrm{mp} 183-185^{\circ}$ $\mathrm{C} ;[\alpha]_{\mathrm{D}}+46.6\left(\mathrm{CHCl}_{3}\right)$; UV 220; IR (KBr) $\gamma_{\max } 3640$ $(\mathrm{OH}), 1700(\mathrm{C}=\mathrm{O}) ;{ }^{1} \mathrm{H}$ NMR and ${ }^{13} \mathrm{C}$ NMR, see Table 2; $m / z 192$ 177(17), 161(100) 144(25); anal. calcd for $\mathrm{C}_{10} \mathrm{H}_{8} \mathrm{O}_{4} \% \mathrm{C}$ 62.04, \% $\mathrm{H} \mathrm{4.21, \%} \mathrm{O} \mathrm{33.2;} \mathrm{found} \mathrm{\%} \mathrm{C}$ $61.9, \%$ H 4.43, \% O 32.8.

\subsection{Xanthotoxin $\left(4 \mathrm{C}_{12} \mathrm{H}_{8} \mathrm{O}_{4}\right)$}

White, amorphous powder (26 mg; from $\mathrm{CH}_{2} \mathrm{Cl}_{2}$-EtOAc 1:1); mp $\left.158-160^{\circ} \mathrm{C} ; \alpha\right]_{\mathrm{D}}+46.6\left(\mathrm{CHCl}_{3}\right)$. The data from IR (KBr), ${ }^{1} \mathrm{H}$ NMR and ${ }^{13} \mathrm{C}$ NMR proposed that compound 3 is xanthotoxin [16-20]; anal. calcd for $\mathrm{C}_{12} \mathrm{H}_{8} \mathrm{O}_{4}$ \% C 66.64, \% H 3.71, \% O 29.2; found \% C 66.49, \% H $3.43, \%$ O 29.8 .

\subsection{Biological studies}

\subsubsection{Anti-inflammatory activity}

The anti-inflammatory activity was evaluated by hind paw oedema method [23]. Albino rats of weighing 100$150 \mathrm{~g}$, of either three compounds (2-4), using Indomethacin as a standard, were divided into five groups of six animals. The animals were maintained under normal environmental conditions. To each group, with the exception of the control group, the tested compounds $(0.01 \mathrm{mg} / 100 \mathrm{~g}$ of body weight) were administered, injected. To one group, the standard drug Indomethacin $(0.01 \mathrm{mg} / 100 \mathrm{~g})$ was administered. After $1 \mathrm{~h}$, carrageenan $(0.1 \mathrm{ml}, 1 \% \mathrm{w} / \mathrm{v}$ solution in sterile saline) was injected into the sub-plantar tissue of the left paw of all the animals. The right paw served as the reference noninflamed paw for comparison. The initial paw volume was measured using a plethysmograph within $30 \mathrm{~s}$ of the injection. After $3 \mathrm{~h}$, the final paw volume of each animal was measured. The percentage of reduction in the paw volume was calculated by subtracting the difference between the right and left hind paw volumes in the treated group from the difference in the control group and dividing it by the difference in the control group. The anti-inflammatory tivity of the tested compounds and the standard reference drug was determined using the formula, \% anti-inflammatory activity $=\left(1-V_{\mathrm{t}} / V_{\mathrm{c}}\right)$ 
$\times 100$, where $V_{\mathrm{t}}$ represented the mean increase in paw volume of rats treated with test compounds and $V_{\mathrm{c}}$ represented the mean increase in paw volume in the control group of rats.

\subsubsection{Anti-viral activity}

In this study, the compounds (2-4) were evaluated for their anti-viral activity. These compounds were tested against two mammalian viruses, HSV-1 and VSV. The antiviral activity were determined by means of the end titration technique that depends on the ability of plant extract dilutions to inhibit the produced cytopathogenic effect and expressed as reduction factor $\left(R_{\mathrm{f}}\right)$ of the viral titer.

\section{Conclusion}

Ammi majus $L$. being local medicinal plants with great abundance in west of Egypt are shown in rich in antiviral and anti-inflammatory activities, including phytochemicals coumarin. \{\} These results give them the privilege to start intensive studies for isolation of these biologically active compounds for local drug-design programs. In addition, $A$. majus $L$. is considered as a good source of 6-hydroxy-7-methoxy coumarin (3) which was identified as the major coumarin. Also, this is the first study to report the occurrence of compound (3).

\section{Acknowledgements}

The authors are very grateful to the Botany Department, Faculty of Science and Pharmacology Department, Faculty of Pharmacy, Zagazig University, for their help in identification of the plants and farmacological testes.

\section{Author details}

${ }^{1}$ Faculty of Specific Education, Zagazig University, Zagazig, Egypt ${ }^{2}$ Chemistry Department, Faculty of Science, Zagazig University, Zagazig, Egypt

\section{Competing interests}

The authors declare that they have no competing interests.

Received: 3 October 2011 Accepted: 12 January 2012

Published: 12 January 2012

\section{References}

1. Egyptian Pharmacopoeia (1972) General Organization for Government Printing, Cairo, 32

2. Central Council for Research in Unani Medicine (1987) Standardisation of single drugs of Unani medicine-Part I. Ministry of Health and Family Welfare, New Delhi

3. Hakim RE (1969) Rediscovery of a treatment for vitiligo. Clio Medica 4:277-289

4. El-Mofty AM (1948) A preliminary clinical report on the treatment of leucodermia with Ammi majus Linn. J Egypt Med Assoc 31:651-665

5. Fahmy IR, Abu-Shady H (1948) The isolation and properties of ammoidin, ammidin and majudin and their effect in the treatment of leukodermia. $Q$ Pharm Pharmacol 21:499-503

6. El-Mofty AM (1952) Further study on treatment of leucodermia with Ammi majus Linn. J R Egypt Med Assoc 35:1-19

7. NAPRALERT database University of Illinois at Chicago, Chicago, IL (an online database available directly through the University of Illinois at Chicago or through the Scientific and Technical Network (STN) of Chemical Abstracts Services) Accessed 9 February 2001
8. Parrish JA (1974) Photochemotherapy of psoriasis with oral methoxsalen and long wave ultraviolet light. N Engl J Med 291:1207-1211. doi:10.1056/ NEJM197412052912301.

9. El-Mofty AM, El-Mofty M (1980) Psoralen photochemotherapy in contrast to chemotherapy of psoriasis. Med J Cairo Univ 48:71-83

10. El-Mofty AM, El-Sawalhy H, El-Mofty M (1994) Clinical study of a new preparation of 8-methoxypsoralen in photochemotherapy. Int J Dermatol 33:588-592. doi:10.1111/j.1365-4362.1994.tb02904.x

11. El-Mofty AM, El-Sawalhy H, El-Mofty M (1995) Photochemotherapy in the treatment of post tinea versicolor hypopigmentation. Med J Cairo Univ 61(4):632-637

12. Yasuhara-Bell J, Yang Y, Barlow R, Trapido-Rosenthal H, Lu Y (2010) In vitro evaluation of marine-microorganism extracts for anti-viral activity. Virol 7:182. doi:10.1186/1743-422X-7-182.

13. Soltan MM, Zaki AK (2009) Antimicrobial and antiviral activities of some Egyptian medicinal plants. J Ethnopharmacol 126(1):102-107. doi:10.1016/j. jep.2009.08.001.

14. Lacy C (2000) Drug information handbook. Lexicomp, Hudson, OH, 6

15. Wagner H, Wisenauer ML (1995) Phytotherapie. [Phytotherapy.]. Gustav Fischer, Stuttgart

16. Abu-Mustafa EA, Fayez MBE (1961) Natural coumarins. I. Marmesin and marmesinin, further products from the fruits of Ammi majus L. J Org Chem 26:161-166. doi:10.1021/jo01060a039.

17. Hilal SH, Haggag MY (1975) A thin-layer chromatography (TLC) colorimetric assay of furocoumarins. Egypt J Pharm Sci 16:495-499

18. Abdulla WA (1978) Preliminary studies on the anti-schistosomal effect of Ammi majus L. Egypt J Bilharziasis 4:19-26

19. Ivie GW (1978) Linear furocoumarins (psoralens) from the seed of Texas Ammi majus L. (Bishop's weed). J Agric Food Chem 26:1394-1403. doi:10.1021/jf60220a023.

20. Singab ANB (1998) Acetylated fl avonol triglycosides from Ammi majus L. Phytochemistry 49:2177-2180. doi:10.1016/S0031-9422(98)00417-8.

21. Meera M, Kumar S, Kalidhar SB (1999) Phytochemical investigation of Parkinsonia aculeata. Indian J Pharm Sci 61:315-316

22. Heilbron I, Cook AH, Bunbury HM, Hey DH (1965) Dictionary of organic compounds. Eyre and Spottiswoode, London

23. Winter CA, Risley EA, Nuss GW (1962) Carrageenan-induced oedema in hind paw of the rat as an assay for anti-inflammatory drugs. Proc Soc Exp Biol Med 111:544-547

doi:10.1186/2191-2858-2-1

Cite this article as: Selim and Ouf: Anti-inflammatory new coumarin from the Ammi majus L. Organic and Medicinal Chemistry Letters 2012 2:

\section{Submit your manuscript to a SpringerOpen ${ }^{\circ}$ journal and benefit from:}

- Convenient online submission

- Rigorous peer review

- Immediate publication on acceptance

- Open access: articles freely available online

- High visibility within the field

- Retaining the copyright to your article

Submit your next manuscript at $>$ springeropen.com 